\title{
Penguatan Lembaga DPD Melalui Amandemen Ulang Lembaga MPR
}

\author{
Jamaludin Ghafur \\ Departemen Kajian PSHK FH UII Yogyakarta \\ Jamaludin_ghafur@yahoo.com
}

\begin{abstract}
The inclusion of Regional Representatives Council (DPD) in the parliament, side by side with House of Representatives (DPR), suggests that the parliamentary system applied in Indonesia is bicameral system, since there are two bodies within this parliament. However, considering that People's Consultative Assembly (MPR) is not a joint session between DPR and DPD but rather an independent body with independent authorities, can be said accordingly that Indonesian parliamentary system is a "grey" system stands between bicameral and tricameral system.
\end{abstract}

Keywords:Penguatan, amandemen ulang, MPR, DPD

\section{Pendahuluan}

Gagasan awal direformasinya struktur MPR pada amandemen keempat UUD 1945 lebih disebabkan karena ketidakjelasan daripada strukur MPR itu sendiri. Adanya utusan golongan dan utusan daerah dianggap tidak jelas mewakili apa dan siapa. Bahkan adanya unsur utusan golongan dan utusan daerah yang dilakukan dengan pengangkatan bukan dengan pemilihan tersebut telah memunculkan paktik korupsi kekuasaan karena memang tidak ada kriteria dan ukuran yang jelas siapa yang pantas diangkat untuk mewakili siapa.

Setidaknya ada 2 (dua) kritik atas struktur MPR pada sebelum perubahan. ${ }^{1}$ Pertama, permasalahan representasi. Total keanggotaan MPR sebelum amandemen UUD 1945 ditetapkan sebanyak 1000 orang

${ }^{1}$ Bivitri Susanti, "Fungsi dan Peran Ideal Dewan Perwakilan Daerah", www.sarwono.net, (terakhir diakses, 03 April 2008) 
(sebelumnya 900 orang). Dari jumlah tersebut, terdapat 425 orang (sebelumnya 400 orang) anggota DPR yang merangkap sebagai anggota MPR (anggota MPR/DPR) dan sisanya merupakan anggota MPR yang bukan merupakan anggota DPR, yaitu Utusan Daerah (UD) dan Utusan Golongan (UG). Dengan demikian, ada dua jenis keanggotaan MPR, yaitu: anggota MPR/DPR dan anggota MPR yang bukan anggota DPR. Belum ada penjelasan yang memadai tentang struktur MPR tersebut serta alasan mengapa ada lembaga MPR dan DPR yang terpisah. Alasan yang bisa diperkirakan, menurut Bagir Manan, adalah keanggotaan MPR diperluas dengan hadirnya utusan daerah dan golongan, di samping anggota DPR itu sendiri.

Permasalahan kedua, ada ketidakjelasan sistem perwakilan yang dianut yang menyebabkan tidak berjalannya mekanisme checks and balances. Peran lembaga legislatif praktis hanya dilaksanakan oleh DPR, sementara anggota MPR dari utusan daerah dan utusan golongan tidak bisa dikategorikan sebagai legislatif karena kerjanya yang terbatas setiap lima tahun.

Berangkat dari pemikiran untuk mengefektifkan keberadaan utusan golongan dan utusan daerah inilah kemudian komposisi struktur MPR pasca amandemen meniadakan kedua utusan tersebut dan menggantinya dengan DPD. Sehingga, saat ini struktur MPR hanya terdiri dari anggota DPR yang merepresentasikan kepentingan rakyat secara umum yang biasa kita kenal dengan sebutan prinsip 'political representation' dan anggota DPD sebagai penampung aspirasi daerah yang merupakan cermin prinsip 'regional representation'. ${ }^{2}$

Penghapusan utusan golongan tersebut menurut Bagir Manan, ${ }^{3}$ lebih didorong oleh kepentingan pragmatik daripada konseptual. Pertama, tidak mudah menentukan golongan yang diwakili. Kedua, cara pengisiannya mudah menimbulkan kolusi politik antara golongan yang diangkat dengan yang mengangkat. Perubahan sistem utusan golongan daerah dimaksudkan agar lebih demokratik dan meningkatkan keikut sertaan daerah dalam penyelenggaraan sehari-hari praktik negara dan pemerintahan, disamping sebagai forum memperjuangkan kepentingan daerah.

${ }^{2}$ Pasal 2 ayat 1 UUD 1945.

${ }^{3}$ Bagir Manan, DPR, DPD, dan MPR dalam UUD 1945 Baru, Cetakan Ketiga, FH UII Press, Yogyakarta, 2005, hlm. 81. 
Ditinjau dari susunan keanggotaan MPR pasca amandemen UUD 1945 tersebut mengindikasikan bahwa parlemen Indonesia akan didesain menjadi parlemen bikameral. Walaupun demikian, hal ini masih menimbulkan perdebatan apakah sistem parlemen kita saat ini adalah bikameral ataukah trikameral? Hal ini tidak terlepas dari eksistensi MPR yang masih diberikan beberapa kewenangan tersendiri dengan komposisi keanggotaannya yang menurut Pasal 2 ayat (1) terdiri dari anggota Dewan Perwakilan Rakyat dan anggota Dewan Perwakilan Daerah bukan terdiri dari DPR dan DPD secara kelembagaan, sehingga akan sangat sulit untuk tidak mengatakan bahwa MPR adalah lembaga yang berdiri sendiri selain DPR dan DPD. Oleh karenanya sering dikatakan bahwa sistem perwakilan Republik Indonesia pasca perubahan UUD 1945 "tanpa kelamin."4

Menurut Pasal 3 UUD 1945, MPR berwenang (i) mengubah dan menetapkan Undang-Undang Dasar; (ii) melantik Presiden dan/atau Wakil Presiden; (iii) dapat memberhentikan Presiden dan/ atau Wakil Presiden dalam masa jabatannya menurut Undang-Undang Dasar.

Berubahnya komposisi keanggotaan MPR ternyata juga diikuti oleh perubahan yang sangat mendasar atas keberadaan MPR itu sendiri dimana sebelum perubahan UUD 1945 merupakan satu-satunya lembaga pemegang kedaulatan rakyat dengan kewenangan yang tidak terbatas, namun setelah perubahan kedudukan MPR menjadi sederajad dan sejajar dengan lembaga tinggi negara lainnya. Menurut Ismail Sunny, supremasi suatu lembaga negara mengandung makna bahwa: ${ }^{5}$

a. Badan tersebut mempunyai "legal power" untuk menetapkan segala sesuatu yang ditegaskan oleh Undang-Undang Dasar.

b. Tidak ada suatu otorita tandingan, yang berarti bahwa tidak seorang pun atau suatu badan pun yang mempunyai kekuasaan atau kewenangan untuk melanggar atau menyampingkan sesuatu yang telah diputuskan oleh badan tersebut.

Gagasan meniadakan kedudukan MPR sebagai lembaga tertinggi negara secara konseptual ingin menegaskan, MPR bukan satu-satunya lembaga yang melaksanakan kedaulatan rakyat. Setiap lembaga yang mengemban tugas-tugas politik negara dan pemerintahan (tidak termasuk

${ }^{4}$ I Gde Pantja Astawa, "Kata Pengantar, dalam Abdi Suhana, Sistem Ketatanegaraan Indonesia Pasca Perubahan UUD 1945, FM, Bandung, 2007

${ }^{5}$ Philipus M. Hadjon, "Lembaga Tertinggi dan Lembaga-Lembaga Tinggi Negara", PT Bina Ilmu, Surabaya, 1987, hlm. 1-2. 
kekuasaan kehakiman) adalah pelaksana kedaulatan rakyat dan harus tunduk dan bertanggungjawab kepada rakyat. ${ }^{6}$

Permasalahan yang ingin dikaji dalam tulisan ini adalah bagaimana mendesaian ulang lembaga MPR supaya terjadi penguatan pada lembaga DPD.

\section{Model-Model Badan Perwakilan}

Menurut I Gde Pantja Astawa, ${ }^{7}$ perbincangan teoritik tentang sistem perwakilan, pada esensinya bicara tentang struktur organisasi yang ada di badan perwakilan rakyat (parlemen). Untuk itu dikenal sistem perwakilan satu kamar (unikameral), dua kamar (bikameral), dan tiga kamar (three cameral/multy cameral), meskipun sistem yang terakhir ini nyaris tidak lagi dijumpai sekarang.

\section{Sistem Unikameral}

Sistem parlemen/perwakilan unikameral atau satu kamar pada saat ini merupakan model perwakilan yang paling banyak digunakan di dunia. ${ }^{8}$ Pada umumnya unikameral banyak dianut oleh negara dengan bentuk negara kesatuan ${ }^{9}$ walaupun hal ini tidak harus selalu demikian.

Dalam buku Parliament of the Word (1986) dikatakan bahwa meskipun berusaha untuk menguji secara sistematis terhadap alasan-alasan yang bervariasi mengenai banyaknya negara yang mengadopsi sistem unikameral yang melebihi cakupan studi tentang parlemen, ada beberapa hal yang dapat dicatat. Negara-negara yang berukuran kecil lebih menyukai untuk memilih satu kamar daripada dua kamar, seperti masalah keseimbangan kekuatan politik sangat kecil kesulitannya untuk memecahkannya daripada dalam suatu negara besar. Di negara-negara kesatuan sosialis, sistem bikameral dipandang membawa kepada

${ }^{6}$ Bagir Manan, DPR, DPD ..., Op., Cit., hlm 83

${ }^{7}$ Abdi Suhana, Sistem Ketatanegaraan Indonesia Pasca Perubahan UUD 1945, FM, Bandung, 2007, hlm. 58.

${ }^{8}$ Jimly Asshiddiqie, Konsolidasi Naskah UUD 1945 Setelah Perubahan Keempat, Pusat Studi Hukum Tata Negara FH UI, Jakarta, 2002, hal. 33.

${ }^{9}$ Menurut studi Tsebelis dan Jeannette Money (1997) disimpulkan bahwa 99 persen negara federal menganut sistem bikameral, sedangkan 84 persen negara kesatuan menganut sistem unikameral. Lihat Pandji Santosa "Impian Parlemen Bikameral" http:/ / www.pikiran-rakyat.com. (terakhir diakses Feb. 16, 2008) 
komplikasi-komplikasi, penundaan-penundaan dan biaya-biaya, dengan sedikit kompensasi yang menguntungkan. ${ }^{10}$

Fungsi dewan atau majelis legislatif dalam sistem unikameral itu terpusat pada satu badan legislatif tertinggi dalam struktur negara. Isi aturan mengenai fungsi dan tugas parlemen unikameral ini beragam dan bervariasi dari satu negara ke negara lain, tetapi pada pokoknya serupa bahwa secara kelembagaan fungsi legislatif tertinggi diletakkan sebagai tanggung jawab satu badan tertinggi yang dipilih oleh rakyat. ${ }^{11}$

Ada beberapa keunggulan daripada parlemen bikameral, menurut Dahlan Thaib keunggulan dimaksud adalah: ${ }^{12}$

a. Kemungkinan untuk dapat cepat meloloskan undang-undang (karena hanya satu badan yang diperlukan untuk mengadopsi rancangan undang-undang sehingga tidak perlu lagi menyesuaikan dengan usulan yang berbeda-beda)

b. Tanggung jawab lebih besar (karena anggota legislatif tidak dapat menyalahkan majelis lainnya apabila suatu undang-undang tidak lolos, atau bila kepentingan warga negara terabaikan).

c. Lebih sedikit anggota terpilih sehingga lebih mudah bagi masyarakat untuk memantau kepentingan mereka; dan

d. Biaya lebih rendah bagi pemerintah dan pembayar pajak.

\section{Sistem Bikameral}

Ada banyak definisi yang dikemukakan oleh para ahli tentang bikameralisme. Salah satunya dikemukakan oleh Henry Campbell Black ${ }^{13}$ yang mendefinisikannya sebagai berikut :

"Bikameral Sistem : A term applied by Jeremy Bentham to the division of the legislative body into two chamber, as in the United States (senate and house).

${ }^{10}$ Reni Dwi Purnomowati, Implementasi Sistem Bikameral dalam Parlemen Indonesia, PT RajaGrafindo Persada, Jakarta, 2005, hlm. 12.

${ }^{11}$ Jimly Asshiddiqie, Konsolidasi Naskah....., Op. Cit., hlm. 36.

${ }^{12}$ Dahlan Thaib, "Menuju Parlemen Bikameral (Studi Konstitusional Perubahan Ketiga UUD 1945)”, artikel pada Jurnal Hukum, FH UII, Vol. 10. Nomor 23, 2003, hlm. 88-89.

${ }^{13}$ Henry Campbell Black, Blacks' Law Dictionary., Definittion of the Terms Phrases and English Jurisprudence, Anciet and Modern, Ed. V, West Group, Minnesota, 1991, hlm. 111. 
Sistem bikameral adalah wujud institusional dari lembaga perwakilan atau parlemen sebuah negara yang terdiri atas dua kamar (majelis). Majelis yang anggotanya dipilih dan mewakili rakyat yang berdasarkan jumlah penduduk secara generik disebut majelis pertama atau majelis rendah, dan dikenal juga sebagai House of Representatives. Majelis yang anggotanya dipilih atau diangkat dengan dasar lain (bukan jumlah penduduk), disebut sebagai majelis kedua atau majelis tinggi dan di sebagaian besar negara $(60 \%)$ disebut sebagai Senate (dengan berbagai variasinya seperti sénat, senato, senado, senatuil). ${ }^{14}$

Dari segi keanggotaan antara dewan tinggi dan dewan rendah yang dalam konteks Indonesia adalah DPR dan DPD haruslah ada pembedaan. Hal ini penting untuk menghindari pengertian keterwakilan ganda (double representation) dalam mengartikan fungsi parlemen yang dijalankah oleh kedua dewan tersebut. Menurut Jimly Asshiddiqie ${ }^{15}$ untuk membedakan keanggotaan DPR dan DPD, dapat ditentukan adanya tiga kemungkinan formula; (1) masa jabatan anggotanya dapat dibedakan, DPD dapat ditentukan lebih lama daripada masa jabatan DPR, (2) jika kita ingin meniru Prancis dan Amerika Serikat, jabatan DPD sebagai institusi dapat ditentukan enam tahun, tetapi setiap tiga tahun diadakan pergantian melalui pemilihan umum lagi; dan/ atau (3) keanggotaan DPD itu tidak dipilih secara langsung melalui pemilu seperti halnya anggota DPR, melainkan - misalnya - dipilih saja oleh DPRD di tiap-tiap provinsi, dari calon-calon yang diajukan oleh DPRD kabupaten/kota.

Selain terdiri dari dua kamar seperti yang diuraikan di atas, bikameralisme juga menuntut adanya keseimbangan kewenangan diantara keduanya. Keberadaan masing-masing kamar berfungsi sebagai penyeimbang satu sama lain yang saling melakukan fungsi kontrol (check and balances). Sehingga lazimnya tidak ada salah satu kamar yang kemudian menjadi subordinat bagi kamar yang lain karena masing-masing mempunyai kewenangan yang seimbang.

Bagi Indonesia, ada beberapa pertimbangan menuju sistem dua kamar. ${ }^{16}$

14 Ginanjar Kartasasmita, "Bikamerisme di Indonesia", http:// www.ginandjar.com., hlm. 2-3, (terakhir diakses 2 Maret 2008).

${ }^{15}$ Jimly Asshiddiqie, Format Kelembagaan Negara dan Pergeseran Kekuasaan dalam UUD 1945, FH UII Press, Yogyakarta, 2005, hlm, 167.

${ }^{16}$ Bagir Manan, Teori Dan Politik Konstitusi, Ctk. Kedua, FH UII Press, Yogyakarta, 2004, hlm 60. 
1. Seperti diuraikan Montesquieu, sistem dua kamar merupakan suatu mekanisme check and balances antara kamar-kamar dalam satu badan perwakilan.

2. Penyederhanaan sistem badan perwakilan. Hanya ada satu badan perwakilan tingkat pusat yang terdiri dari dua unsur yaitu unsur yang langsung mewakili seluruh rakyat dan unsur yang mewakili daerah.

3. Wakil daerah menjadi bagian dari pelaksanaan fungsi parlemen (membentuk undang-undang, mengawasi pemerintah, menetapkan APBN, dan lain-lain). Dengan demikian segala kepentingan daerah terintegrasi dan dapat dilaksanakan sehari-hari dalam kegiatan parlemen. Hal ini merupakan salah satu faktor untuk menguatkan persatuan, menghindari integrasi.

4. Sistem dua kamar akan lebih produktif. Segala tugas dan wewenang dapat dilakukan setiap unsur. Tidak perlu menunggu atau bergantung pada satu badan seperti DPR sekarang.

\section{Sistem Trikameral}

Sistem trikameral atau perwakilan tiga kamar merupakan badan perwakilan yang di dalamnya terdiri atas tiga kamar dimana satu sama lainnya memiliki kedudukan yang sederajad dan mempunyai kewenangan masing-masing. Walaupun hampir di seluruh dunia tidak ada negara yang mengadopsi sistem ini, namun Indonesia menerapkan hal tersebut dengan komposisi parlemen saat ini yang terdiri dari DPR, DPD dan MPR.

Menurut Jimly Asshiddiqie, setelah perubahan keempat UUD 1945, keberadaan MPR yang selama ini disebut sebagai lembaga tertinggi negara itu memang telah mengalami perubahan yang sangat mendasar, tetapi keberadaannya tetap ada sehingga sistem yang kita anut tidak dapat disebut sebagai unikameral atau bikameral, melainkan sistem tiga kamar (trikameral), dasar-dasar yang mendukung bahwa menganut sistem parlemen tiga kamar adalah sebagai berikut: ${ }^{17}$

1. Ternyata bahwa DPD sama sekali tidak diberi kewenangan legislatif, meskipun hanya sederhana sekalipun. DPD hanya memberikan saran atau pertimbangan, dan sama sekali tidak berwenang mengambil keputusan apa-apa di bidang legislatif.

${ }^{17}$ Jimly Asshiddiqie, Konstitusi \& Konstitusionalisme Indonesia, Konstitusi Press, Jakarta, 2004, hlm. 150. 
2. Pasal 2 ayat (1) UUD 1945 menyatakan, "MPR terdiri atas anggota DPR dan anggota DPD yang dipilih melalui pemilihan umum dan diatur lebih lanjut dengan undang-undang", tidak seperti kongres Amerika Serikat yang dikatakan terdiri atas DPR dan Senat, atau Staten General Belanda yang terdiri atas Eerste Kamer dan Tweede Kamer.

3. Ternyata lembaga MPR juga mempunyai kewenagan-kewenangan dan pimpinan tersendiri. Dari kedua hal itu, maka MPR dapat disebut sebagai institusi tersendiri, sehingga struktur parlemen Indonesia seperti dikemukakan di atas dapat disebut sebagai parlemen tiga kamar (trikameralisme).

\section{Pembangian Dan Pemisahan Kekuasaan}

Lahirnya konsep "trias politica" pertama kali dicetuskan oleh John Locke (1632-1704) dan Montesquieu (1689-1755). Secara umum ajaran tentang trias politica ini mengajarkan tentang arti penting pembagian atau pemisahan kekuasaan dalam penyelenggaraan pemerintahan agar kekuasaan absolut yang hanya terpusat pada seseorang bisa dihindari. Hal ini penting karena dalam perjalanan sejarah peradaban manusia, kekuasaan yang hanya terpusat pada satu pribadi selalu menimbulkan tirani dan kediktatoran. Untuk kepentingan inilah kedua tokoh di atas kemudian membagi kekuasaan negara secara garis besar menjadi tiga bagian.

John Locke seperti dikemukakan dalam bukunya yang berjudul "Two treatises on civil government" membagi kekuasaan menjadi tiga kekuasaan yaitu: Pertama, kekuasaan legislatif yaitu kekuasaan untuk membuat peraturan perundang-undangan. Kedua, kekuasaan eksekutif yaitu kekuasaan untuk melaksanakan undang-undang dan mengadili jika terjadi pelanggaran atas undang-undang tersebut. Ketiga, federatif yaitu kekuasaan untuk melindungi keamanan negara dalam hubungannya dengan negara lain atau dengan kata lain kekuasaan untuk melakukan hubungan luar negeri.

Pandangan Montesquieu tentang pemisahan kekuasaan sebenarnya tidak terlalu jauh berbeda dengan apa yang telah dikemukakan oleh John Locke bahkan dapat dikatakan pembagian kekuasaan oleh Montesquieu merupakan penyempurnaan atas kelemahan atau kekuarangan dari konsep trias politica John Locke. Salah satu sorotan Montesquieu atas teori John Locke tersebut adalah tiadanya lembaga kekuasaan yang mandiri 
untuk menghukum bagi mereka yang melanggar undang-undang karena fungsi kontrol tersebut dilakukan oleh lembaga yang sebenarnya pelaksana dari undang-undang yang dibuat oleh lembaga legistatif yaitu eksekutif.

Jadi berbeda dengan John Locke yang memasukkan kekuasaan yudikatif ke dalam kekuasaan eksekutif, Montesquieu memandang kekuasaan pengadilan (yudikatif) itu sebagai kekuasaan yang berdiri sendiri. Hal ini dipengaruhi oleh pengalamannya sebagai hakim, Montesquieu mengetahui bahwa kekuasaan eksekutif itu berlainan dengan kekuasaan pengadilan. Sebaliknya kekuasaan hubungan luar negeri yang disebut John Locke sebagai kekuasaan federatif, dimasukkan ke dalam kekuasaan eksekutif. ${ }^{18}$ Sehingga pembagian kekuasaan menurut Montesquieu seperti yang diuraikan dalam bukunya " $L$ 'Esprit des Lois (The Spirit of Law)" adalah kekuasaan legislatif, eksekutif dan yudikatif.

Berbeda pandangan adalah C. Van Vollenhoven ${ }^{19}$ dalam buku "Staatsrecht over Zee" yang menyatakan dalam suatu negara ada 4 (empat) macam kekuasaan yaitu:

1) Pemerintahan (Bestuur),

2) Perundang-undangan,

3) Kepolisian dan,

4) Pengadilan

Pada awal kelahirannya teori trias politica ini merupakan hal yang amat sangat ideal sebagai suatu tawaran konsep yang dianggap mampu meminimalisir penyalahgunaan kekuasaan seperti dikemukakan oleh Lord Acton bahwa 'power tends to corrupt, absolute power corrupt absolutely'. Namun seiring berkembangnya praktek dan teori ketatanegaraan, menurut Jimly Asshiddiqie, ${ }^{20}$ konsep trias politica yang diidealkan oleh Montesquieu ini jelas tidak relevan lagi diterapkan secara murni dewasa ini, sehingga tidak mungkin lagi mempertahankan satu argumentasi bahwa ketiga organisasi tersebut hanya berurusan secara eksklusif dengan salah satu dari ketiga fungsi kekuasaan tersebut. Kenyataan dewasa menunjukkan bahwa hubungan antar cabang kekuasaan itu tidak mungkin tidak saling bersentuhan, dan bahkan ketiganya bersifat sederajat

\footnotetext{
${ }^{18}$ Miriam Budiardjo, Miriam Budiardjo, Dasar-Dasar Ilmu Politik, Ctk. Keduapuluh dua, PT. Gramedia Pustaka Utama, Jakarta, 2001, hlm. 152

${ }^{19}$ Mirza Nasution, Negara dan Konstitusi, http://library.usu.ac.id. (terakhir diakses, tanggal 26 April 2008)

${ }^{20}$ Jimly, Perkembangan dan Konsolidasi Lembaga Negara Pasca Reformasi, Sekretariat Jendral dan Kepaniteraan MK RI, Jakarta, 2006, hlm. 35
} 
dan saling bersentuhan, dan bahkan ketiganya bersifat sederajat dan saling mengendalikan satu sama lain sesuai dengan prinsip check and balances.

\section{MPR sebagai Forum Sidang Bersama DPR dan DPD.}

Walaupun secara kelembagaan DPD telah memberikan corak tersendiri atas model perwakilan Indonesia, namun keterbatasan kewenangan dan tugas yang dipunyainya telah menimbulkan kepincangan sistem check and balances yang ingin dibangun, khususnya antara DPD dan DPR. Kekerdilan daripada DPD tersirat dalam pasal 22D tentang kewenangan DPD yang sama sekali tidak memberikan hak eksekusi, tetapi sebatas pertimbangan saja.

Secara khusus, wewenang DPD dalam bidang legislasi yaitu pengajuan usul, ikut dalam pembahasan dan memberikan pertimbangan, dijabarkan oleh UU SUSDUK sebagai berikut:

1. Mengajukan kepada DPR RUU yang berkaitan dengan otonomi daerah, hubungan pusat dan daerah, pembentukan dan pemekaran, dan penggabungan daerah, pengelolaan sumber daya alam, dan sumber daya ekonomi lainnya serta yang berkaitan dengan perimbangan keuangan pusat dan daerah. Usulan ini diajukan kepada DPR. Selanjutnya DPR akan mengundang DPD untuk membahas sesuai Tatib DPR. Pembahasan RUU ini dilakukan sebelum DPR membahas RUU dengan Pemerintah. ${ }^{21}$

2. Membahas RUU yang berkaitan dengan otonomi daerah, hubungan pusat dan daerah; pembentukan, pemekaran, dan penggabungan daerah; pengelolaan sumber daya alam, dan sumber daya ekonomi lainnya serta yang berkaitan dengan perimbangan keuangan pusat dan daerah, yang diajukan baik oleh DPR maupun oleh Pemerintah. Dalam hal ini DPD diundang oleh DPR untuk melakukan pembahasan RUU bersama dengan Pemerintah pada awal Pembicaraan Tingkat I sesuai Peraturan Tatib DPR. Pembicaraan Tingkat I ini dilakukan bersama antara DPR, DPD, dan pemerintah dalam hal penyampaian pandangan dan pendapat DPD atas RUU, serta tanggapan atas pandangan dan pendapat dari masing-masing lembaga. Pandangan, pendapat, dan tanggapan DPD tersebut dijadikan sebagai masukan untuk pembahasan lebih lanjut antara DPR dan Pemerintah. ${ }^{22}$

\footnotetext{
${ }^{21}$ Pasal 42 UU No. 22 Tahun 2003 tentang Susunan dan Kedudukan DPR, DPD, dan MPR.

${ }^{22}$ Ibid., Pasal 43.
} 
3. Memberikan pertimbangan kepada DPR atas RUU APBN dan RUU yang berkaitan dengan pajak, pendidikan, dan agama. Pertimbangan tersebut diberikan dalam bentuk tertulis sebelum memasuki tahapan pembahasan antara DPR dan Pemerintah. Pertimbangan tersebut menjadi bahan bagi DPR dalam melakukan pembahasan dengan Pemerintah. ${ }^{23}$

Sebagai representasi daerah, kehadiran DPR tentulah sangat diharapkan andil dan perannya untuk menyuarakan aspirasi kepentingan masyarakat daerah di tingkat nasional. Hal ini penting untuk disadari bahwa ketimpangan dan ketidak merataan sirkulasi sumber daya antar daerah, khususnya antara jawa dengan luar jawa selama ini telah menjadi suatu alasan nyata munculnya separatisme dan pergolakan di daerah. Kebijakan yang sentralistik selama Orde Lama dan Orde Baru telah menimbulkan kekecewaan daerah terhadap pemerintahan pusat.

Latar belakang pembentukan Dewan Perwakilan Daerah Republik Indonesia (DPD RI) sebagaimana tercantum dalam lampiran Keputusan MPR Nomor 4/MPR/2004 tentang Laporan Badan Pekerja MPR RI mengenai Hasil Kajian Komisi Konstitusi tentang Perubahan UUD 1945, menegaskan bahwa keberadaan DPD RI dalam struktur ketatanegaraan Indonesia itu antara lain dimaksudkan untuk:

a. Memperkuat ikatan daerah-daerah dalam wadah Negara Kesatuan Republik Indonesia dan memperteguh persatuan kebangsaan seluruh daerah-daerah.

b. Meningkatkan agregasi dan akomodasi aspirasi dan kepentingan daerah-daerah dalam perumusan kebijakan nasional berkaitan dengan negara dan daerah-daerah;

c. Mendorong percepatan demokrasi, pembangunan dan kemajuan daerah-daerah secara serasi dan seimbang

Oleh karenanya, pemberdayaan dan penguatan terhadap DPD merupakan sesuatu yang niscaya untuk mengakomodasi kebutuhan daerah demi satu kepentingan nasional yaitu keutuhan Negara Kesatuan Republik Indonesia (NKRI) dan kesejahteraan rakyatnya. Untuk meningkatkan efektivitas dan pemberdayaan DPD dalam sistem ketatanegaraan yang demokratis, ada beberapa prinsip yang kiranya perlu menjadi pegangan: ${ }^{24}$

\footnotetext{
${ }^{23}$ Ibid., Pasal 44.

${ }^{24}$ Ginanjar Kartasasmita, “Bikameralisme..., Op., Cit., hlm. 2-3.
} 
1. Dalam bidang legislasi kedudukan DPD tidak perlu sepenuhnya setara atau sama luasnya dengan DPR.

2. Kewenangan legislatif DPD cukup terbatas pada bidang-bidang yang sekarang sudah tercantum dalam UUD, dan itupun tetap bersama (share) dengan DPR (tidak mengambil alih).

3. Kewenangan legislasi DPD tersebut dapat dirumuskan dengan berbagai cara, seperti yang telah berlaku di negara-negara lain, mulai dari hak menolak (veto), mengembalikan ke DPR atau hanya menunda.

4. Namun dalam hal kewenangan pengawasan (oversight) DPD harus memiliki kekuatan hukum yang sama dengan DPR, agar supaya pengawasan tersebut bisa efektif. Untuk menghindari terjadinya duplikasi dengan DPR dapat diatur pembagian kewenangan dan tanggung jawab pengawasan antara kedua lembaga tersebut. Misalnya, pengawasan DPD lebih terfokus di daerah dan DPR di pusat.

Kehadiran DPD sebagai wakil kewilayahan non-partai sejatinya diharapkan mampu memberikan harapan baru ditengah krisis legitimasi masyarakat atas kinerja DPR yang selama ini kurang begitu membanggakan sebagai wakil rakyat dan terkesan hanya menjadi kepanjangan tangan kepentingan partai politiknya semata dari pada berpihak pada kepentingan konstituennya. Namun sayangnya, harapan tersebut untuk saat ini sepertinya masih jauh panggang dari api. Selain keterbatasan kewenangan yang dimiliki oleh DPD sebagai kamar kedua di parlemen, limitasi kuantitas yang tidak lebih dari 1/3 jumlah anggota DPR, sepertinya DPD tidak akan bisa berbuat bayak dalam pengambilan keputusan. Meski tingkat legitimasi kedua dewan sama karena berasal dari proses electoral (pasal 22C dan pasal 22E perubahan ketiga UUD 1945) kesenjangan kuantitatif dipastikan akan berdampak pada minimnya tingkat pengaruh DPD terhadap proses agregasi pembuatan keputusan. ${ }^{25}$

${ }^{25}$ Agus Haryadi, "Bikameral Setengah Hati”, Kompas, (15 Mei 2002), hal. 4. Dalam hal jumlah anggota mungkin tidak selalu memengaruhi terhadap kekuatan kamar kedua dalam sistem bikameralisme. Dalam pengambilan-pengambilan keputusan, misalnya saja keputusan yang diambil secara voting, mungkin bisa kalah, tetapi kekuasaan sebenarnya adalah kekuasaan yang diberikan terhadap kamar kedua tersebut oleh konstitusi. Dalam hal ini dapat diambil contoh adalah House of Lord (kamar kedua/majelis tinggi) Inggris, jumlahnya lebih besar dari House of Commons (kamar pertama/ majelis rendah) tetapi kekuasaannya, kewenangannya lebih banyak diberikan pada House of Commons yang jumlah anggotanya lebih sedikit. Lihat Reni Dwi Purnomowati, Implementasi Sistem..., Op., Cit, hlm. 6. 
Konsepsi bikameralisme mengandung makna bahwa hanya ada dua kamar dalam parlemen yakni majelis rendah (House of Common) dan majelis tinggi (House of Lord) dalam istilah parlemen Inggris, Senate dan House Of Representative dalam istilah Negara Amerika Serikat, atau Eerste Kamer dan Tweede Kamer dalam istilah Belanda serta DPR dan DPD dalam konsep badan perwakilan Indonesia haruslah saling mengontrol dan menyeimbangkan (checks and balances) demi kinerja yang lebih baik, berkualitas dan akuntabel.

Pada mulanya, tujuan dibentuknya parlemen bikameral dihubungkan dengan bentuk negara federasi yang memerlukan dua kamar majelis. Kedua majelis itu perlu diadakan untuk maksud melindungi formula federasi itu sendiri. Tetapi, dalam perkembangannya bersamaan dengan pergeseran kearah bentuk negara kesatuan, maka sistem bikameral itu juga dipraktikkan di lingkungan negara-negara kesatuan. Dua alasan utama yang dapat dikemukakan penggunaan sistem bikameral ini adalah: ${ }^{26}$

a. Adanya kebutuhan akan perlunya suatu keseimbangan yang lebih stabil antara pihak eksekutif dan legislatif, the unbridled power of a single chamber being restrained by the creation of a second chamber recruited on a different basis.

b. Keinginan untuk membuat sistem parlementer berjalan, jika tidak lebih efesien, setidak-tidaknya lebih lancar (lebih smooth), melalui suatu majelis (chamber) yang disebut revising chamber untuk memelihara a careful check on the sometimes hasty decisions of a fist chamber.

Pilihan bikameral atau unikameral sebagai model badan perwakilan akan selalu tergantung pada masing-masing realitas politik, sosial, budaya dan aspek sejarah masing-masing negara. Inggris misalnya, model dua kamar pada parlemen Inggris lahir karena adanya proses demokratisasi badan perwakilan dimana awalnya hanya ada majelis tinggi (House of Lord) yang terdiri dari kaum bangsawan dan kelompok kelas atas, namun kemudian muncul majelis rendah (House of Commons) sebagai representasi keterwakilan dari masyarakat umum.

Sistem dua kamar di Amerika Serikat, merupakan hasil kompromi antara negara bagian yang berpenduduk banyak dengan yang berpenduduk sedikit. House of Representatives (DPR) mewakili seluruh

${ }^{26}$ Jimly Asshiddiqie, Pergumulan Peran Pemerintah dan Parlemen dalam Sejarah, Telaah Perbandingan Konstitusi Berbagai Negara, UI Press, Jakarta, 1996, hlm. 39. 
rakyat. Setiap negara bagian diwakili sesuai dengan jumlah penduduk. Senate (senat) mewakili negara bagian. Setiap negara bagian diwakili dua orang senator tanpa membeda-bedakan negara bagian yang berpenduduk banyak (seperti New York atau California) dengan yang berpenduduk lebih kecil (seperti Alaska, atau Nevada). ${ }^{27}$

Namun demikian, tujuan, efektifitas dan efesiensi anggaran negara haruslah menjadi tolak ukur keberadaan lembaga MPR agar lembaga perwakilan di Indonesia bisa berfungsi secara maksimal demi memperjuangkan kepentingan rakyat. Adanya unsur pimpinan dan kesekretariatan yang tersendiri pada MPR yang terpisah sama sekali dari pimpinan DPR dan DPD, serta beberapa kewenangan yang masih melekat, menunjukkan bahwa MPR merupakan lembaga permanen yang berdiri sendiri. Dengan format seperti ini, sama sekali tidak tampak urgensinya karena memang kewenangan yang ada tersebut hampir semuanya bersifat insidentil. Kalaupun ada yang bersifat rutin itupun hanya terjadi setiap lima (5) tahun sekali yakni melantik Presiden dan Wakil Presiden.

Berangkat dari inefesiensi dan inefektifitas serta untuk menghindari adanya lembaga penunjang yang memboroskan dari segi anggaran inilah mestinya kedepan MPR haruslah didorong hanya menjadi nama sidang atau forum bersama antara DPD dan DPR. Sidang tersebut dilakukan ketika harus memutuskan sesuatu hal yang memerlukan persetujuan bersama antara DPR dan DPD yang telah ditetapkan oleh konstitusi.

Hal tersebut akan bisa direalisasikan hanya dengan cara mengamandemen ulang UUD 1945, khususnya tentang pasal-pasal yang mengatur lembaga MPR dan DPD berikut kewenangannya. Menurut pendapat beberapa ahli dan politisi, beberapa pasal dalam UUD 1945 yang harus di amandemen agar terbangun sistem bikameral yang efektif pada parlemen Indonesia adalah:

1. Pasal 2 (1) diusulkan dirubah sehingga berbunyi:

“Majelis Permusyawaratan Rakyat terdiri atas Dewan Perwakilan

Rakyat dan Dewan Perwakilan Daerah yang dipilih melalui pemilihan umum yang diatur lebih lanjut dengan undang-undang" ${ }^{28}$

\footnotetext{
${ }^{27}$ Bagir Manan, Teori dan..., Op., Cit., hlm. 59-60.

${ }^{28}$ Rumusan usul perubahan ini ingin menegaskan bahwa dalam parlemen bicameral bukan anggota perseorangan yang menjadi tolak ukur tetapi kelembagaaannya.
} 
2. Pasal 7 (A) diusulkan dirubah sehingga berbunyi:

“Presiden dan/atau Wakil Presiden dapat diberhentikan dalam masa jabatannya oleh Majelis Permusyawaratan Rakyat atas usul Dewan Perwakilan Rakyat dan/atau Dewan Perwakilan Daerah. ${ }^{29}$

3. Pasal 7 (C ) diusulkan dirubah sehingga berbunyi:

"Presiden tidak dapat membekukan dan/atau membubarkan Dewan Perwakilan Rakyat dan Dewan Perwakilan Daerah".

4. Pasal 22D UUD 1945 diusulkan dirubah sebagai berikut:

Ayat (1) diusulkan dirubah sehingga berbunyi:

“Dewan Perwakilan Daerah memegang kekuasaan membentuk undang undang bersama Dewan Perwakilan Rakyat yang berkaitan dengan otonomi daerah, hubungan pusat dan daerah, pembentukan dan pemekaran serta penggabungan daerah, pengelolaan sumber daya alam dan sumber daya ekonomi lainnya, serta yang berkaitan dengan perimbangan keuangan pusat dan daerah".

Ayat (2) diusulkan dirubah sehingga berbunyi:

"Dewan Perwakilan Daerah ikut membahas serta memberikan pertimbangan kepada Dewan Perwakilan Rakyat atas rancangan undang-undang anggaran pendapatan dan belanja negara dan rancangan undang-undang yang berkaitan dengan pajak, pendidikan, dan agama".

Ayat (3) diusulkan dirubah sehingga berbunyi:

“Dewan Perwakilan Daerah melakukan pengawasan atas pelaksanaan undang undang mengenai: otonomi daerah, pembentukan, pemekaran dan penggabungan daerah, hubungan pusat dan daerah, pengelolaan sumber daya alam dan sumber daya ekonomi lainnya, pelaksanaan anggaran pendapatan dan belanja negara, pajak, pendidikan, dan agama serta menyampaikan hasil pengawasannya itu kepada Dewan Perwakilan Rakyat dan Pemerintah untuk ditindaklanjuti".

\footnotetext{
${ }^{29}$ Penambahan 'dan/ atau Dewan Perwakilan Daerah' menurut Dahlan Thaib adalah sesuai dengan prinsip check and balances. Lihat Dahlan Thaib, "Peran Ideal DPD dalam Sistem Ketatanegaraan Indonesia", Makalah disampaikan pada acara diskusi publik dengan tema "Peran Sinergitas DPD RI dengan Pemerintahan Daerah dalam Pelaksanaan Otonomi Daerah", diselenggarakan oleh Pusat Studi Hukum Konstitusi FH UII bekerjasama dengan DPD RI, Yogyakarta, 12 Februari 2008, hlm. 8.
} 


\section{Penutup}

Berdasarkan uraian di atas dapat disimpulkan bahwa,k. sebagai representasi daerah, kehadiran DPD tentu sangat diharapkan andil dan perannya untuk menyuarakan aspirasi kepentingan masyarakat daerah. Tetapi DPD sama sekali tidak diberi kewenangan legislatif. DPD hanya memberikan saran atau pertimbangan, dan sama sekali tidak berwenang mengambil keputusan apa-apa di bidang legislatif. Penguatan lembaga DPD akan bisa direalisasikan hanya dengan cara mengamandemen ulang UUD 1945, khususnya tentang pasal-pasal yang mengatur lembaga MPR dan DPD berikut kewenangannya. Ke depan MPR haruslah didorong menjadi forum bersama antara DPD dan DPR ketika harus memutuskan sesuatu hal yang memerlukan persetujuan bersama antara DPR dan DPD yang telah ditetapkan oleh konstitusi.

\section{Daftar Pustaka}

Buku-buku

Abdi Suhana, Sistem Ketatanegaraan Indonesia Pasca Perubahan UUD 1945, Bandung , FM , 2007.

Bagir Manan, DPR, DPD, dan MPR dalam UUD 1945 Baru, Ctk ketiga, Yogyakarta, FH UII Press, 2005.

, Teori Dan Politik Konstitusi, Ctk. Kedua, Yogyakarta, FH UII Press, 2004.

Jimly Asshiddiqie, Perkembangan dan Konsolidasi Lembaga Negara Pasca Reformasi, Jakarta, Sekretariat Jendral dan Kepaniteraan MK RI, 2006.

- Format Kelembagaan Negara dan Pergeseran Kekuasaan dalam UUD 1945, Yogyakarta, FH UII Press, 2005.

, Konstitusi \& Konstitusionalisme Indonesia, Jakarta, Konstitusi Press, 2004.

Konsolidasi Naskah UUD 1945 Setelah Perubahan Keempat, Jakarta, Pusat Studi Hukum Tata Negara FH UI, 2002.

Pergumulan Peran Pemerintah dan Parlemen dalam Sejarah, Telaah Perbandingan Konstitusi Berbagai Negara, Jakarta, UI Press. 1996.

Miriam Budiardjo, Dasar-Dasar Ilmu Politik, Ctk. Keduapuluh dua, Jakarta, PT. Gramedia Pustaka Utama, 2001.

Philipus M. Hadjon, "Lembaga Tertinggi dan Lembaga-Lembaga Tinggi Negara", Surabaya, PT Bina Ilmu, 1987. 
Reni Dwi Purnomowati, Implementasi Sistem Bikameral dalam Parlemen Indonesia, Jakarta, PT RajaGrafindo Persada, 2005.

Peraturan perundang-undangan

Undang-Udang Dasar 1945, Jakarta, Sekretariat Jenderal dan Kepaniteraan MK RI, 2007.

UU No. 22 Tahun 2003 tentang Susunan dan Kedudukan DPR, DPD, dan MPR.

Jurnal dan Makalah

Jurnal Hukum FH UII, Edisi No. 23 Vol. 10, 2003, hlm. 88-89.

Dahlan Thaib, 2008, "Peran Ideal DPD dalam Sistem Ketatanegaraan Indonesia", Makalah disampaikan pada acara diskusi publik "Peran Sinergitas DPD RI dengan Pemerintahan Daerah dalam Pelaksanaan Otonomi Daerah", Pusat Studi Hukum Konstitusi FH UII bekerjasama dengan DPD RI, Yogyakarta, 12 Februari 2008.

Koran dan Internet

Kompas, tanggal 15 Mei 2002.

Bivitri Susanti, Fungsi dan Peran Ideal Dewan Perwakilan Daerah, dalam http: \\www.sarnono.net.

Pandji Santosa, Impian Parlemen Bikameral, dalam http:/ /www.pikiranrakyat.com.

Ginanjar Kartasasmita, Bikamerisme di Indonesia, dalam http:// www.ginandjar.com.

Mirza Nasution, Negara dan Konstitusi, http://library.usu.ac.id. 


\section{Index}

A

amandemen UUD 1945398

C

check and balances 402

checks and balances 397, 408

D

double representation 401

DPD 396, 397, 398, 399, 401, 402, 405, 406, 407, 409, 411

E

Eerste Kamer 403, 408

H

House of Common 408

House of Commons 408

House of Lord 408

House Of Representative 408

House of Representatives 401

I

I Gde Pantja Astawa 399

J

Jeremy Bentham 400

Jimly Asshiddiqie 402

K

Keputusan MPR Nomor 4/MPR/2004 406

L

legal power 398 
$\mathbf{M}$

Montesquieu 402

$\mathbf{P}$

political representation 397

$\mathbf{R}$

regional representation 397

S

Senate 408, 409

Sistem Bikameral 400

Sistem Trikameral 402

Sistem Unikameral 399

Staten General 403

$\mathbf{T}$

three cameral 399

trikameral 402

trikameralisme 403

Tweede Kamer 403, 408

U

unikameral 399 
Jamaludin Ghafur. Penguatan Lembaga... 415 
JURNAL HUKUM NO. 3 VOL. 14 JULI 2007: 366 - 412 
Jamaludin Ghafur. Penguatan Lembaga... 417 
JURNAL HUKUM NO. 3 VOL. 14 JULI 2007: 366 - 412 
Jamaludin Ghafur. Penguatan Lembaga... 419 
JURNAL HUKUM NO. 3 VOL. 14 JULI 2007: 366 - 412 
Jamaludin Ghafur. Penguatan Lembaga... 421 
JURNAL HUKUM NO. 3 VOL. 14 JULI 2007: 366 - 412 
Jamaludin Ghafur. Penguatan Lembaga... 423 
JURNAL HUKUM NO. 3 VOL. 14 JULI 2007: 366 - 412 